\title{
GOAL ORIENTATION ATLET DI MASA PANDEMI COVID-19
}

\author{
Sitti Fathimah Herdarina Darsim ${ }^{1}$, Retno Hanggarani Ninin ${ }^{2}$
}

\author{
${ }^{1}$ Program Studi Psikologi Profesi, Universitas Padjadjaran \\ Email: sitti19001@mail.unpad.ac.id \\ ${ }^{2}$ Program Studi Psikologi Profesi, Universitas Padjadjaran \\ Email: rhninin@unpad.ac.id
}

Masuk : 28-07-2021, revisi: 26-09-2021, diterima untuk diterbitkan :09-10-2021

\begin{abstract}
Goal orientation is a motivational orientation that can affect the way individuals pursue their goals and competencies in achieving those goals. Goal orientation is one of the psychological aspects that can have an impact due to the current pandemic situation. Athletes must do independent training, even though they are in preparation for the championship. This study aims to know the athletes goal orientation during the Covid-19 pandemic. This study uses a qualitative approach. Participants have the following criteria: (1) Athletes who play an active role in one sport for at least 5 years and (2) are facing the impact of the Covid-19 pandemic in the form of having to do independent training. Participants in this study amounted to 3 people with the details of 1 taekwondo athlete, 1 jujitsu athlete, and 1 fencing athlete. Data is collected by interview technique. The finding fact is divided into several categories and labeled with special terms. After that, the facts found were interpreted. The results showed that the goal orientation in three subjects is dominated by Mastery Goal Orientation (MGO). They try to develop skills and competencies to compete via the internet by their own initiative. Moreover, one of the athletes, Y showed Performance Approach Goal Orientation (PAPGO), an extrinsic motivation to get an appraisal or avoid punishment from the coach.
\end{abstract}

Keywords: Goal orientation, athlete, pandemic, Covid-19

\begin{abstract}
ABSTRAK
Goal orientation merupakan orientasi motivasi yang dapat mempengaruhi cara individu dalam mengejar tujuan dan kompetensi mereka dalam mencapai tujuan tersebut. Goal orientation menjadi salah satu aspek psikologis yang dapat terdampak akibat situasi pandemi saat ini. Para atlet harus melakukan latihan mandiri, padahal mereka sedang dalam persiapan untuk menghadapi kejuaraan. Penelitian ini bertujuan untuk mengetahui gambaran goal orientation atlet di masa pandemi Covid-19. Penelitian ini menggunakan pendekatan kualitatif. Partisipan memiliki kriteria: (1) Atlet yang berperan aktif pada satu cabang olahraga selama minimal 5 tahun dan (2) sedang menghadapi dampak pandemi Covid-19 dalam bentuk keharusan melakukan latihan mandiri. Partisipan dalam penelitian ini berjumlah 3 orang dengan rincian 1 orang atlet taekwondo, 1 orang atlet jujitsu, dan 1 orang atlet anggar. Pengambilan data dilakukan dengan teknik wawancara. Fakta temuan dibagi ke dalam beberapa kategori dan dilabeli dengan istilah khusus. Setelah itu, fakta yang ditemukan dimaknai. Hasil penelitian menunjukkan bahwa goal orientation pada ketiga subjek didominasi oleh Mastery Goal Orientation (MGO). Mereka berusaha mengembangkan keterampilan dan kompetensi untuk bertanding melalui melalui internet dengan inisiatif sendiri. Selain itu, ditemukan Performance Approach Goal Orientation (PAPGO) pada seorang subjek yang mengorientasikan latihannya untuk mendapatkan penilaian atau menghindari hukuman dari pelatih.
\end{abstract}

Kata Kunci: Goal orientation, atlet, pandemi, Covid-19

\section{PENDAHULUAN Latar Belakang}

Menurut Undang-undang Nomor 3 Tahun 2005 tentang Sistem Keolahragaan Nasional Bab VI Pasal 17 disebutkan bahwa olahraga prestasi adalah olahraga yang membina dan mengembangkan olahragawan secara terencana, berjenjang, dan berkelanjutan melalui kompetisi untuk mencapai prestasi dengan dukungan ilmu pengetahuan dan teknologi keolahragaan. Di lingkungan Komite Olimpiade Amerika, telah diterapkan seperangkat ilmu dalam pembinaan olahraga prestasi, salah satunya adalah psikologi olahraga (Lutan, 1997). Harsono (dalam Singgih et al., 1996) mengatakan bahwa psikologi olahraga terkait proses-proses mental atlet menjadi kontributor yang semakin menentukan dalam pembinaan serta peningkatan prestasi atlet. Kinerja yang berhasil 
dalam olahraga tidak hanya mengharuskan atlet untuk menjadi sehat dan bugar secara fisik, tetapi juga siap secara mental untuk bermain (Junge, 2000).

Masalah yang dihadapi oleh atlet olahraga prestasi pada umumnya terbagi dalam beberapa kategori, yaitu: 1) masalah individu atau pribadi; 2) masalah yang relatif bertahan (dialami dalam jangka waktu yang lama); 3) masalah terkait dengan peningkatan prestasi; dan 4) masalah terkait dengan kemenangan dan kekalahan (Sullivan \& Nashman, 1998). Sebagian besar atlet memiliki tingkat stres yang tinggi (Rohmansyah, 2017). Penelitian lain menunjukkan bahwa tingkat kecemasan dan stres atlet menjelang pertandingan tergolong tinggi (Makharisma, 2014). Kecemasan sering kali meningkat sebelum bertanding dan disebabkan oleh bayangan beratnya tugas dan pertandingan yang akan datang. Selama pertandingan berlangsung, tingkat kecemasan biasanya mulai menurun dan naik lagi ketika mendekati akhir pertandingan, terutama apabila skor pertandingan sama atau hanya berbeda sedikit (Husdarta, 2011).

Pandemi membuat banyak pertandingan olah raga ditunda atau dibatalkan, tanpa kepastian akan waktu pelaksanaannya di masa yang akan datang. Situasi tersebut memunculkan kecemasan baru pada para atlet. Penundaan dan ketidakjelasan jadwal pertandingan dan peniadaan pemusatan latihan dapat menjadi salah satu faktor penyebabnya (Azizah, 2020). Jika di masa sebelum pandemi pelatih yang bertanggung jawab atas program latihan, maka ketika pandemi para atlet harus bertanggung jawab penuh dan mandiri atas program pelatihannya, seperti menentukan jadwal, tempat latihan, bahkan target latihannya, atau pelibatan orang lain sebagai sparing partner. Latihan mandiri tersebut sebelum pandemi adalah hal yang tidak biasa dalam olahraga prestasi. Selain itu, ketidakjelasan target latihan dan target prestasi (pertandingan) akibat pandemi menjadi situasi yang menantang bagi para atlet. Bagi atlet olahraga prestasi yang terbiasa berlatih untuk menghadapi seleksi pertandingan, latihan mandiri dalam konteks pandemi saat ini merupakan tantangan baru yang perlu dihadapi dan diatasi (Nugraha et al., 2021, Saputro, 2021).

Studi dalam psikologi pendidikan telah menunjukkan bagaimana pencapaian dalam konteks kompetitif sosial, seperti sekolah atau bidang olahraga (Pepi et al., 2006; Alesi et al., 2015). Teori tujuan pencapaian (achievement goal theory) dapat menjadi dasar dalam menjelaskan karakter individu yang ingin menunjukkan kemampuan dan kompetensi diri mereka ketika berpartisipasi (Nicholls, 1989). Teori achievement goal juga mengacu pada teori orientasi tujuan (goal orientation). Menurut Dowson dan McInerney (2001), goal orientation merupakan cara individu dalam mengejar tujuan dan kompetensi dalam mencapai tujuan tersebut. Goal orientation adalah orientasi motivasi yang dapat mempengaruhi perilaku belajar mereka dari waktu ke waktu. Penelitian di bidang pendidikan menggambarkan goal orientation sebagai cara individu mengorientasikan diri mereka dalam menghadapi kesulitan (Elliott \& Dweck, 1988; VandeWalle, 1997). Peneliti terdahulu (Elliot, 1999; Elliot \& Church, 1997; VandeWalle, 1997) menggunakan kerangka trikotomi dalam penelitian mereka, yaitu membagi goal orientation menjadi tiga dimensi yang berbeda, yaitu penguasaan (mastery), pendekatan kinerja (performance approach), dan orientasi tujuan penghindaran kinerja (performance avoidance goal orientation).

Mastery Goal Orientation (MGO) mengacu pada individu yang memiliki motivasi intrinsik dalam usaha mengembangkan keterampilan dan kompetensi mereka melalui penguasaan situasi yang menantang. Atlet yang memiliki orientasi ini akan menganggap kesulitan sebagai peluang untuk belajar (Dweck et al., 1993), cenderung cemas terhadap tugas yang lebih mudah atau tidak menantang, dan mampu mengevaluasi tugas untuk menunjukkan pencapaian mereka (Sujan, Weitz, \& Kumar, 1994). Mereka memiliki keinginan kuat dalam meningkatkan kompetensi pribadi, menguasai pengalaman baru, dan memperoleh keterampilan baru (VandeWalle, 1997). 
Mereka bertahan di belakang kegagalan dan menggunakan hambatan yang mereka temui untuk lebih meningkatkan kinerja mereka (Elliot, 1999).

Performance Approach Goal Orientation (PAPGO) terkait dengan keinginan seseorang untuk membuktikan kompetensinya dan bermaksud mendapatkan penilaian untuk hal tersebut (VandeWalle, 1997). Kunci yang membedakan orientasi ini dengan MGO adalah adanya motif ekstrinsik yaitu untuk mendapatkan penilaian dari orang lain. Atlet dengan PAPGO lebih suka mencapai kinerja tinggi dengan sedikit usaha dan mengejar peluang yang mendapatkan evaluasi positif (DeShon \& Gillespie, 2005). Sementara itu, Performance Avoidance Goal Orientation (PAVGO) adalah upaya menghindari situasi yang dapat menunjukkan ketidakmampuan mereka dan menyebabkan mereka menerima penilaian negatif tentang hal tersebut (VandeWalle, 1997). Secara umum, mereka menganggap situasi yang menantang sebagai ancaman yang dapat mengungkapkan perilaku dan ketidakmampuan mereka yang kurang baik (Elliot A. J., A Conceptual History of The Achievement Goal Construct, 2005).

Penelitian-penelitian sebelumnya menemukan bahwa goal orientation mampu menjelaskan karakter individu dalam berpartisipasi di bidangnya. Dampak dari situasi pandemi terhadap proses latihan atlet dan jadwal pertandingan menimbulkan rasa ingin tahu peneliti terhadap respon atlet terkait keharusan untuk melakukan latihan mandiri. Dasar pertimbangan dari pilihan-pilihan yang diambil dapat menggambarkan orientasi tujuan yang dimiliki oleh seorang atlet.

\section{Rumusan Masalah}

Berdasarkan latar belakang di atas, maka yang menjadi rumusan masalah adalah "Bagaimana gambaran goal orientation atlet di masa pandemi Covid-19?"

\section{METODE PENELITIAN}

Penelitian ini adalah penelitian kualitatif dengan metode eksplorasi. Sumber data penelitian diperoleh dari wawancara melalui media sosial (WhatsApp) yang dilakukan oleh peneliti dengan menggunakan teknik wawancara semi terstruktur. Peneliti menggunakan pertanyaan terbuka, namun terdapat batasan tema yaitu Goal Orientation dan alur pembicaraan (guide interview) sebagai kontrol ketika melakukan wawancara kepada subjek. Partisipan dalam penelitian ini adalah 3 orang atlet yang berperan aktif pada cabang olahraganya masing-masing (taekwondo, jujitsu, dan anggar) selama minimal 5 tahun. Selain itu, partisipan-partisipan ini juga sedang menghadapi dampak pandemi Covid-19 yaitu keharusan melakukan latihan mandiri.

Wawancara melalui WhatsApp diawali dengan perkenalan, penyampaian tujuan penelitian, dan permohonan kepada subjek untuk kesediaannya menjadi partisipan. Wawancara berlanjut ke tahap pengambilan data bagi subjek yang bersedia. Subjek diberikan daftar pertanyaan yang telah disusun dan beberapa pertanyaan tambahan guna mendapatkan jawaban yang lebih lengkap. Seluruh data kemudian dipindahkan ke dalam Microsoft Word (transkrip wawancara). Analisis data dilakukan dengan menggunakan teknik analisis Miles dan Huberman. Tahap pertama adalah melakukan reduksi data dari transkrip. Data yang sudah direduksi disajikan dalam bentuk tabel. Tabel berisi kalimat-kalimat yang dikelompokkan dalam beberapa kategori dan dilabeli istilah khusus. Pelabelan kategori dilakukan dengan berdasar pada kerangka konseptual Goal Orientation (Elliot, 1999; Elliot \& Church, 1997; VandeWalle, 1997). Selanjutnya, data pada tabel dijelaskan dalam pembahasan.

\section{HASIL DAN PEMBAHASAN}


Penelitian ini bertujuan untuk menggambarkan goal orientation atlet di masa pandemi Covid-19, yaitu situasi ketika seluruh pertandingan olahraga ditiadakan, padahal tujuan latihan bagi hampir sebagian besar atlet olahraga prestasi adalah mendapatkan kemenangan dari berbagai kompetisi olahraga. Terdapat tiga dimensi goal orientation yang bisa dipetakan berdasarkan perspektif Elliot (1999); Elliot \& Church (1997); VandeWalle (1997), yaitu 1) motivasi intrinsik untuk mengembangkan keterampilan dan kompetensi melalui penguasaan situasi yang menantang (MGO), 2) motivasi ekstrinsik untuk membuktikan kompetensi diri melalui penilaian orang lain (PAPGO), dan 3) minimalisasi upaya untuk menghindari situasi di mana mereka tidak kompeten dan kurang mampu dari rekan-rekan mereka (PAVGO). Data dari ketiga subjek disajikan di tabel berikut:

\section{Tabel 1}

Gambaran Goal Orientation Atlet di Masa Pandemi Covid-19

\begin{tabular}{|c|c|c|c|c|}
\hline No. & Aspek & Subjek Y & Subjek K & Subjek R \\
\hline 1. & Identitas & $\begin{array}{l}\text { Perempuan, atlet } \\
\text { Jujitsu }\end{array}$ & $\begin{array}{l}\text { Laki-laki, atlet } \\
\text { Anggar }\end{array}$ & $\begin{array}{l}\text { Laki-laki, } \\
\text { atlet Taekwondo }\end{array}$ \\
\hline 2. & MGO & $\begin{array}{l}\text { "Yang membuat saya tetap } \\
\text { berlatih utamanya untuk } \\
\text { menjaga kesehatan fisik } \\
\text { karena dasar bela diri juga } \\
\text { sama seperti olahraga pada } \\
\text { umumnya. Karenarjika } \\
\text { latihan untuk } \\
\text { mempersiapkan event } \\
\text { belum ada kepastian kapan } \\
\text { akan diadakan dalam waktu } \\
\text { terdekat. Mengikuti intruksi } \\
\text { pelatih menurut saya sudah } \\
\text { pilihan tepat karna lebih tau } \\
\text { akan diarahkan seperti apa } \\
\text { kami nantinya." } \\
\text { "Ada, karna selalu } \\
\text { berpositif pandemi ini tidak } \\
\text { akan membekukan kegiatan } \\
\text { pertandingan sampai } \\
\text { bertahun2." }\end{array}$ & $\begin{array}{l}\text { "Sebagai atlet muda saya } \\
\text { tetap menjaga kondisi fisik } \\
\text { tanpa harus berdiam diri } \\
\text { di rumah dan menunggu } \\
\text { waktu yang sangat lama } \\
\text { untuk kembali latihan } \\
\text { lagi." }\end{array}$ & $\begin{array}{l}\text { "Menjaga kondisi badan } \\
\text { aja sii, biar ga terlalu } \\
\text { kaget juga nanti pas balik } \\
\text { beraktifitas kayak biasa } \\
\text { lagi, jaga-jaga biar ga } \\
\text { sakit, sama biar ga } \\
\text { genduutt." }\end{array}$ \\
\hline
\end{tabular}




\begin{tabular}{|c|c|c|c|c|}
\hline 3 & PAPGO & $\begin{array}{l}\text { "Ngaruh ke semangat } \\
\text { berbeda karna kurang ada } \\
\text { barengan teman dan push } \\
\text { dari pelatih." } \\
\text { "Ngaruh lagi ke teknik } \\
\text { khusus jujitsu, kurang } \\
\text { terasah banyak karena buat } \\
\text { mengeksplor teknik di } \\
\text { lapangan harus ada partner } \\
\text { dan juga harus ada pelatih } \\
\text { yang mendampingi dan } \\
\text { mengarahkan." }\end{array}$ & $\begin{array}{l}\text { "Cuman bedanya di } \\
\text { tempat latihan kita bisa } \\
\text { sparing langsung sama } \\
\text { teman main anggargituga } \\
\text { pakai listrik kan sama- } \\
\text { sama atlet yang tahu } \\
\text { teknik dll. Kalau mandiri } \\
\text { begini sih. Beda banget, } \\
\text { mau sparing sama siapa" }\end{array}$ & - \\
\hline 4 & PAVGO & $\begin{array}{l}\text { "Yang paling } \\
\text { arahan penting } \\
\text { terpenuhi, dan sudah } \\
\text { kalau mood baik } \\
\text { sendiri kamya } \\
\text { dicukupkan. Karena arahan } \\
\text { dari pelatih selama } \\
\text { pandemi ini juga } \\
\text { menyesuaikan kemampuan } \\
\text { atlet untuk bisa latihan di } \\
\text { rumah, beda dengan } \\
\text { biasanya bisa latihan di } \\
\text { lapangan, di gym dan lain- } \\
\text { lain." }\end{array}$ & - & - \\
\hline
\end{tabular}

Tabel 1 menunjukkan bahwa terdapat goal orientation MGO pada subjek Y, K, dan R. Data pada nomor 1 menunjukkan bahwa para atlet memiliki alasan personal untuk mengembangkan keterampilan dan kompetensi mereka di masa pandemi Covid-19. Pada ketiga subjek, orientasinya adalah untuk menjaga kesehatan fisik. Artinya, alasan berlatih di masa pandemi tidak ada hubungannya dengan keikutsertaan dalam pertandingan atau prestasi, melainkan sama dengan alasan orang pada umumnya ketika mereka berolahraga. Data terkait PAPGO menunjukkan bahwa pada subjek Y dan K, keputusan untuk latihan didasari oleh kehadiran teman. Sementara PAVGO, hanya ditemukan pada subjek Y yang keputusan latihannya dipengaruhi oleh pelatih.

Selain data utama berupa goal orientation, ditemukan pula rincian data lain yang relevan dengan goal orientation. Dalam hal jenis latihan yang dilakukan, Subjek R dan K memilih melakukan latihan fisik seperti stretching, work out, melatih beberapa gerakan yang ada dalam cabang olahraga yang ditekuninya, menggunakan barbel, berlari, atau melakukan yoga. Keinginan pribadi untuk menjaga kesehatan fisik menunjukkan bahwa para atlet melakukan latihan untuk memenuhi standar diri. Hal tersebut merupakan ciri perilaku individu yang memiliki MGO (Schunk et al., 2010). Tidak ada pilihan latihan maupun tujuan latihan yang berhubungan dengan pertandingan sebagaimana ketika mereka berada di pemusatan latihan, di bawah binaan pelatih, dan di masa reguler (sebelum pandemi). 
Selain untuk kesehatan fisik, subjek $\mathrm{Y}$ melakukan latihan juga dengan orientasi untuk mempersiapkan event pertandingan selanjutnya, meski pada saat itu belum ada jadwal pasti mengenai event tersebut. Subjek Y mengatakan bahwa ia selalu berpikir positif bahwa pandemi tidak akan membekukan pertandingan sampai bertahun-tahun. Memiliki perasaan yang positif terhadap situasi juga merupakan ciri individu dengan MGO. Selain itu, alasan menjaga kesehatan fisik dan mempersiapkan event selanjutnya menunjukkan adanya motif intrinsik untuk mengembangkan keterampilan dan kompetensinya (Dweck et al., 1993).

Tidak hanya untuk menjaga kesehatan fisik dan mempersiapkan event selanjutnya, latihan juga dilakukan oleh Subjek Y untuk memenuhi arahan pelatih. Menurut Subjek Y, hal yang paling penting baginya adalah menyelesaikan latihan dengan mengikuti arahan pelatih. Sikap Subjek Y menunjukkan adanya motivasi ekstrinsik yaitu keinginan untuk mendapatkan penilaian atau menghindari hukuman dari pelatih. Keinginan tersebut menunjukkan bahwa terdapat ciri PAVGO pada diri subjek Y (VandeWalle, 1997; Bahri, 2000).

Data juga menunjukkan bahwa orientasi motivasi di masa pandemi Covid-19 ternyata juga sangat dipengaruhi oleh suasana hati (mood) atlet. Terkait durasi latihan, ketiga subjek mengatakan tergantung pada mood dan keinginan mereka. Subjek R mengaku bisa berlatih setiap hari atau dua hari sekali ketika sedang rajin. Hal yang sama juga dilakukan oleh Subjek K yang berlatih sekitar empat 4 kali dalam seminggu. Sementara itu, Subjek Y menjelaskan bahwa bila mood-nya baik, ia akan menambah latihannya. Sedangkan bila mood-nya tidak baik, latihan akan dicukupkan. Pilihan ketiga subjek untuk tetap berlatih sendiri di masa pandemi dan bagaimana intensitas latihan tersebut dipengaruhi oleh mood sesuai dengan teori motivasi yang mengemukakan bahwa salah satu faktor yang mempengaruhi motivasi adalah suasana hati (Ardana, 2008).

Pengaruh pandemi terhadap atlet bermacam-macam. Kurangnya fasilitas yang mendukung saat pandemi adalah salah satunya. Subjek R memaparkan bahwa fasilitas di kampus mendukung dan mampu membuatnya berlatih maksimal. Sementara Subjek Y dan K menjelaskan bahwa teman berperan dalam latihan mereka. Pandemi membuat atlet lebih susah karena tidak ada sparing partner dan juga semangat dari teman ketika latihan mandiri di rumah. Selain itu, Subjek Y mengungkapkan bahwa ketika latihan di rumah, ia merasa tidak ada dorongan dari pelatih. Pengakuan dari para subjek tersebut menunjukkan adanya motivasi ekstrinsik yaitu perangsang dari luar diri (Ardana, 2008), seperti lengkapnya fasilitas kampus dapat membantu Subjek R berlatih secara maksimal, kehadiran dan semangat dari teman berperan pada Subjek Y dan K, serta pentingnya peran pelatih pada Subjek Y.

Ditanya perihal cara mereka mengatasi dampak dari pandemi tersebut, Subjek R berkata bahwa tidak ada yang bisa dilakukan selain tetap berlatih. Pernyataan Subjek R tersebut menunjukkan adanya kesadaran bahwa tetap berlatih adalah pilihan terbaik untuk dilakukan saat pandemi, baik untuk alasan kesehatan maupun mempertahankan kompetensi yang dibutuhkan jika kelak pandemi berakhir dan berbagai event pertandingan diselenggarakan kembali. Banyak kejuaraan yang seharusnya ia ikuti namun ditunda akibat pandemi. Menurut Subjek R, selain tetap berlatih, ia juga mengurangi begadang, serta menjaga pola makan untuk mengatasi hambatannya. Tetap berlatih, mengurangi begadang, dan juga tidak asal makan merupakan cara Subjek R bertahan dan berusaha meningkatkan kinerja ketika menemui hambatan yaitu situasi pandemi (Elliot, 1999).

Sedikit berbeda dengan Subjek R, ketika ditanya tentang apa yang ia lakukan untuk mengatasi hambatannya, Subjek Y menjawab bahwa selain tetap fokus latihan mandiri, ia juga mengikuti seminar yang diselenggarakan oleh pengurus pusat. Selain itu, Subjek Y juga melihat-lihat 
referensi teknik baru dari internet dan mencoba melakukan olahraga yang alatnya bisa didapatkan di rumah. Subjek Y menjelaskan bahwa untuk mengurangi kebosanan, ia juga mencoba melakukan banyak kegiatan olahraga yang menyenangkan. Hal-hal baru yang dilakukan oleh Subjek Y tersebut menunjukkan adanya keinginan kuat dalam meningkatkan kompetensi pribadi, memperoleh keterampilan baru, dan menguasai pengalaman baru dalam situasi pandemi (VandeWalle, 1997). Cara Subjek R dan Y menghadapi pandemi di atas menandakan mereka memiliki ciri-ciri individu dengan MGO.

\section{KESIMPULAN DAN SARAN}

Penelitian ini menunjukkan bahwa goal orientation pada ketiga subjek didominasi oleh MGO. Meski cemas terhadap dampak latihan di masa pandemi, subjek tetap berusaha mengembangkan diri mereka. Hal tersebut mereka lakukan dengan berbagai cara. Selain melakukan aktivitas fisik, menjaga pola tidur dan makan, meningkatkan kompetensi dengan pemahaman terhadap materi dan teknik tertentu melalui internet juga dilakukan. Meski begitu, para subjek menunjukkan adanya motivasi ekstrinsik, seperti fasilitas kampus, teman, dan pelatih dapat mendukung dan mampu membuat mereka berlatih maksimal. Hal tersebut menunjukkan bahwa PAPGO juga berperan dalam goal orientation atlet di masa pandemi

Penelitian ini terbatas pada jumlah partisipan dengan hanya tiga latar belakang (cabang olahraga yang ditekuni). Hal tersebut membuat penelitian ini kurang bisa mewakili atlet secara umum dalam hal goal orientation di masa pandemi. Selain itu, wawancara pada penelitian ini juga kurang mendalam karena dibatasi oleh waktu sehingga data yang diperoleh hanya bisa menjelaskan beberapa aspek pada goal orientation.

Ucapan Terima Kasih (Acknowledgement)

Ucapan terima kasih kepada pihak-pihak yang telah membantu pada proses penelitian, terutama para atlet sebagai subjek yang telah bersedia meluangkan waktunya dalam penelitian ini.

\section{REFERENSI}

Alamudi, A. A. (2020, Maret 29). Dampak pandemi Corona, Atlet PPLP Sumut terpaksa dipulangkan. IDN TIMES SUMUT. https://sumut.idntimes.com/sport/arena/hasudungan/dampak-pandemi-corona-atlet-pplpsumut-terpaksa-dipulangkan/full

Alesi, M., Bianco, A., Padulo, J., Luppina, G., Petrucci, M., Paoli, A., ... \& Pepi, A. (2015). Motor and cognitive growth following a football training program. Frontiers in psychology, 6 , 1627. https://doi.org/10.3389/fpsyg.2015.01627

Ardana, K. (2008). Perilaku organisasi. Graha Ilmu.

Azizah, N. (2020, Maret 31). Di tengah pandemi, atlet hadapi risiko kesehatan mental. REPUBLIKA.co.id. https://www.republika.co.id/berita/q82ebt463/di-tengah-pandemiatlet-hadapi-risiko-kesehatan-mental.

Bahri, S. (2000). Psikologi belajar. Rineka Cipta.

DeShon, R. P., \& Gillespie, J. Z. (2005). A motivated action theory account of goal orientation. Journal of Applied Psychology, 90(6), 1096-1127. https://doi.org/10.1037/00219010.90.6.1096

Dowson, M., \& McInerney, M. (2001). Psychological parameters of students social and work avoidance goals: A qualitative investigation. Journal of Educational Psychology, 93(1), 35-42. https://doi.org/10.1037/0022-0663.93.1.35 
Dunn, J. H., \& Dunn, J. (2001). Relationships among the sport competition anxiety test, the sport anxiety scale, and the collegiate hockey worry scale. Journal of Applied Sport Psychology, 13(4), 411-429. https://doi.org/10.1080/104132001753226274

Dweck, C. S., Hong, Y. Y., \& Chiu, C. Y. (1993). Implicit theories: Individual differences in the likelihood and meaning of dispositional influence. Personality and Social Psychology Bulletin, 19(5), 644-656. https://doi.org/10.1177/0146167293195015

Elliot, E. S., \& Dweck, C. S. (1988). Goals: An approach to motivation and achievement. Journal of Personality and Social Psychology, 54(1), 5-12. https://doi.org/10.1037/00223514.54.1.5

Elliot, A. J., \& Church, M. A. (1997). A hierarchical model of approach and avoidance achievement motivation. Journal of Personality and Social Psychology, 72, 218-232. https://doi.org/10.1037/0022-3514.72.1.218

Elliot, A. J. (1999). Approach and avoidance motivation and achievement goals. Educational Psychologist, 34(3), 169-189. https://doi.org/10.1207/s15326985ep3403_3

Elliot, A. J. (2005). A conceptual history of the achievement goal construct. In A. J. Elliot, \& C. S. Dweck, Handbook of competence and motivation (pp. 52-72). Guilford Press.

Haag, H. (1994). Theoretical foundation of sport science as a scientific discipline: Contribution to a philosophy (Meta-Tehory) of sport science. Verlag Karl Hofmann Schondorf.

Hermawan, D. (2020, Maret 26). Dampak COVID-19, Pelatda NPC Sumut bubar dan atlet wajib cek kondisi. IDN TIMES https://sumut.idntimes.com/sport/arena/hasudungan/dampak-covid-19-pelatda-npcsumut-bubar-dan-atlet-wajib-cek-kondisi

Husdarta, H. S. (2011). Psikologi olahraga. Alfabeta.

Junge, A. (2000). The influence of psychological factors on sport injuries: Review of the literature. American Journal of Sports Medicine, 28(5), 10-15. https://doi.org/10.1177/28.suppl_5.s10

Lutan, R. (1997). Manusia dan olahraga. ITB Press.

Makharisma, R. (2014). Tingkat kecemasan dan stres atlet bulutangkis menjelang kompetisi pomnas XIII tahun 2013 di daerah istimewa Yogyakarta [Skripsi, Universitas Negeri Yogyakarta].

Nicholls, J. G. (1989). The competitive ethos and democratic education. Harvard University Press.

Nugraha, M. I., Berliana, B., \& Saputra, M. Y. (2021). Hubungan latihan mandiri selama pandemi Covid-19 dengan kecemasan dan depresi atlet bola tangan pelatda Jawa Barat. Jurnal Kepelatihan Olahraga, 13(1). https://ejournal.upi.edu/index.php/JKO/article/view/32333

Rohmansyah. (2017). Tingkat kecemasan dan stres atlet cabang beladiri menjelang kompetisi porsenasma Palembang. Lembaga Penelitian dan Pengabdian kepada Masyarakat Universitas PGRI Semarang.

Saputro, A. A. (2021). Korelasi latihan mandiri selama pandemi Covid 19 dengan kecemasan dan depresi atlit. Jurnal Porkes, 4(1), 45-49. https://doi.org/10.29408/porkes.v4i1.3470

Schunk, D. H., Pintrich, P. R., \& Meece, J. L. (2010). Motivation in education theory, research, and application third edition. Pearson Education.

Singgih, D. G., Monthy, P. S., \& Myrna, H. S. (1996). Psikologi olahraga: Teori dan praktis. PT Gunung Mulia.

Sujan, H., Weitz, B. A., \& Kumar, N. (1994). Learning orientation, working smart, and effective selling. Journal of Marketing, 58(3), 39-52. https://doi.org/10.2307/1252309

Sullivan, P. A., \& Nashman, H. W. (1998). Self-perceptions of the role of USOC sport psychologists in working with olympic athletes. The Sport Psychologist, 12(1), 95-103. https://doi.org/10.1123/tsp.12.1.95 
Titiyoga, G. W. (2020, April 11). Latihan bersama bayangan. TEMPO. https://majalah.tempo.co/read/olahraga/160156/cara-atlet-olimpiade-berlatih-saat-wabahcorona

Pepi, A., Faria, L., \& Alesi, M. (2006). Personal conceptions of intelligence, self-esteem and school achievement in italian and portuguese students. Adolescence, 41(164), 615-631.

VandeWalle, D. (1997). Development and validation of a work domain goal orientation instrument. Educational and Psychological Measurement, 57(6), 995-1015. https://doi.org/10.1177/0013164497057006009 